\title{
"I Will Not Be Dona Maria": Rethinking Exploitation and Objectification in the Context of Work and Sex Work
}

\author{
Thaddeus Blanchette $^{1, *}$, Ana Paula Da Silva ${ }^{2}$ and Gustavo Camargo $^{1}$ (D) \\ 1 Instituto de Biodiversidade e Sustenabilidade, Federal University of Rio de Janeiro, Macaé 27965-045, Brazil; \\ gustavonhani@gmail.com \\ 2 Eduação do Campo, Federal Fluminense University, Santo Antônio de Pâdua 20241-260, Brazil; \\ mariaflora21@gmail.com \\ * Correspondence: thaddeus.blanchette@gmail.com
}

Citation: Blanchette, Thaddeus, Ana Paula Da Silva, and Gustavo Camargo. 2021. "I Will Not Be Dona Maria": Rethinking Exploitation and Objectification in the Context of Work and Sex Work. Social Sciences 10: 204. https://doi.org/10.3390/socsci 10060204

Academic Editor: Cecilia M. Benoit

Received: 16 December 2020

Accepted: 12 April 2021

Published: 31 May 2021

Publisher's Note: MDPI stays neutral with regard to jurisdictional claims in published maps and institutional affiliations.

Copyright: (c) 2021 by the authors. Licensee MDPI, Basel, Switzerland. This article is an open access article distributed under the terms and conditions of the Creative Commons Attribution (CC BY) license (https:// creativecommons.org/licenses/by/ $4.0 /)$.

\begin{abstract}
In many feminist and sociological accounts of sex work, the concept of exploitation resides on the subjacent notion of objectification, codified in the omnipresent belief that the sex worker sells their body. Sexual objectification supposedly indicates the peculiar and particular effect that sex work is supposed to have on the bodies of human beings involved in this form of toil, being one of the keystones for the belief that sex work is inherently exploitative. In the present article, we intend to investigate the canonical concept of objectification and its (ab)uses in the light of a comparative ethnographic study of sex work and other jobs in the service economy in the cities of Rio de Janeiro (Brazil) and New Orleans (USA). Our argument is that the concept of sexual objectification has its roots in pre-capitalist morality, encoded in Kantian philosophy, that is hardly applicable to real life in the 21st century. A more general and intersectional understanding of objectification and agency in the broader field of engendered labor relations is necessary for us to understand why people choose to engage in sex work, why laws which see sex work as synonymous with exploitation and slavery must be rethought, and how they might be rethought.
\end{abstract}

Keywords: sex work; exploitation; objectification; feminism; sociology of labor; Rio de Janeiro; New Orleans

What it comes down to is this: until they pay people as much money to clean toilets and flip burgers as they do to suck dick, someone will always be willing to sell sex.

\section{-Sex worker activist Monique Prada, Porto Alegre, Brazil}

\section{Introduction}

The article below presents our thoughts regarding exploitation and sex work (Leigh 1997), centering on the concept of objectification. For a powerful wing of feminism that has heavily influenced many States in the confection of sex work laws-particularly those States that have adopted the so-called Swedish Model of client criminalization (Hernes 1987)—objectification has become a shibboleth indicating the inevitable and particular effect that sex work supposedly has on the women involved in this form of labor. As we shall show below, however, concerns regarding the transformation of human beings into things not only underpins feminist understandings of sex work as exploitation, but also classical sociology in its attempts to come to grips with labor exploitation under capitalist modernity. A significant portion of Marxist-informed feminist sociology has moved on from Marx's initial understanding of prostitution as essentially lumpenproletarian, situating sex work as work and thus no more or less necessarily objectifying than other forms of labor (Da Silva and Blanchette 2017). Meanwhile, however, we label the contemporary abolitionist and carceral feminisms (Bernstein 2007) as prohibitionist feminism $^{1}$, rooted in the works of Dworkin (1989) and MacKinnon (1985), which harken back to the idealism of Immanuel Kant in their understanding of sex and work. This allows 
them to imagine sex work as a special kind of exploitation, more generally distinct from labor exploitation.

In the present article, we investigate this canonical concept of (sexual) objectification and its (ab)uses in the light of ethnographic data, comparing sex work with other forms of service economy labor in Rio de Janeiro (Brazil) and New Orleans (USA) in terms of its power to transform humans into objects. In the first two sections below, we employ an intersectional lens incorporating mainly class and gender (but also race, sexuality and socio-geographic positioning) to illustrate domination, the functioning of agency, and the role of seduction and negotiation in the sale of services in the following work contexts: erotic dancer (NO), call girl (RJ), and domestic worker (RJ).

The third part of the article discusses the concept of exploitation in the light of objectification. We argue that the philosophical construction of objectification within feminism has been insufficiently informed by the study of life as it is lived in the world of work in general and sex work in particular. Because of this, the classic feminist critique of objectification in the context of sex work actively avoids engaging with sex work as a choice, undertaken in a social context involving an active rejection of other forms of engendered labor, often perceived by women who sell sex as more objectifying and exploitative.

It is our contention that this (ab)use of the concept of objectification within the debate on sex work has contributed to a situation in which the transformation of humans into objects to be exploited (often described as slaves) ends up being presumed (rather than proven) as a specific and necessary result of morally stigmatized sex work (prostitution, the production of pornography, erotic dance, etc.) and thus a morally distinct form of exploitation that needs must be repressed through criminal law. However, as Marx, Durkheim and Simmel (among many other sociologists) have recognized, the division of labor, the monetization of society, and urbanization have tended to objectify those engaged in work in general. In this context, sex work can appear as an alternative that offers workers a notable improvement both in the conditions of toil and in the possibility of exercising their individual agency within the workplace. In other words, although it is not essentially or necessarily liberating, can be relatively liberating when compared to other forms of labor.

The best possible remedy for this situation, in our view, is an abandonment of the Kantian morality that currently underpins mainstream thought regarding prostitution through a radical re-grounding of the philosophical bases of prostitution law in the lived experiences of sex workers, as presented by politically organized sex workers themselves as stake-holders in law-making within what Janet Halley has coined as "governance feminism".

\section{Materials and Methods}

Following the new lines of discussion regarding pro-sex feminist understandings of sex, as exemplified in Halawi, Soble, Hoffman and Held's new collection on the "philosophy of sex" (Halwani et al. 2018) and, more concretely, Soble (2002) and Papadaki $(2007,2010)$ work on the Kantian notion of "objectification", the authors asked themselves how new understanding of sex as work and work as objectification fit with the lives-as-lived of women involved in sex work.

The ethnographical data related below were collected by in-field participant observation by AUTHORS over the course of several different research projects, but most particularly and recently the Impacts of Mega-Sporting Events on Sex Markets in Rio de Janeiro Project, vetted by the Federal University of Rio de Janeiro Macaé's ethics in research committee. All venues and interlocutors' names have been changed to protect their anonymity, in accordance with the ethical guidelines laid down by the Brazilian Anthropological Association. Some of the material presented in the work that follows below has already been explored in a very small press limited run, exclusively in Portuguese (Blanchette et al. 2014). The current article has been greatly expanded by the inclusion of new data, concepts and analysis. No grant money or other financial aid was used in the conduct of the research presented here. Blanchette and Da Silva are politically involved 
with the sex worker rights movement in Brazil and the growing putafeminista movement, described elsewhere (Blanchette and Da Silva 2018).

The authors had been engaged in observer-participation ethnographic research (see Malinowski [1922] 1976, for a basic outline of what such qualitative research entails) regarding prostitution, sex tourism and human trafficking in Rio de Janeiro since 2004. Their work pushed them into a closer relationship with the political questions surrounding prostitution and, in particular, the hegemonic claim that sex work was "selling one's body" and the worst form of objectification a woman could encounter. The authors began to ask themselves if this was plausible, given the close to 300 open-ended interviews they had conducted with Brazilian female sex workers up to about 2008, which situated sex work as far from being the worst form of labor these women had encountered in their lives.

From 2008 on, the authors thus focused their research on life histories of labor among female heterosexual prostitutes in Rio and São Paulo and several other Brazilian towns and cities. Engaging in participant observation ethnographic fieldwork in the main prostitution districts of these cities (and in the social networks that flow through or are formed in and around such places), the authors mapped some 279 commercial sexual venues in Rio de Janeiro alone, repeatedly visiting the 87 biggest and most reported by clients (on sex consumers internet sites). During the course of our estimated 500 in-field person hours in and around these venues between 2008 and 2010, we collected life histories of work testimony from a further estimated 150 sex workers and observed conversations and behavior of thousands of others. Generally, these were collected via an open-ended interview format that concentrated on three questions:

(1) What work had the women done in the past?

(2) Was their current work (sex work) better or worse than the other forms of labor they had done in the past?

(3) What kind of violence connected to work had they encountered in their lives?

Discussions about exploitation, sex, gender, and objectification naturally flowed from these central questions, which generally took place during the women's unsupervised "down time" in their places of labor (but also took place in a series of other, non-work related environments, including our home, the women's homes, birthday celebrations, non-sex work bars and restaurants and in political venues surrounding the question of anti-trafficking and sex work regulation).

From 2010 on, this project has continued and has ramified in Da Silva's field work into gender, sex, and labor in the rural interior of the state of Rio de Janeiro and Blanchette's similar work in the oil field support cities of the same state.

Given their interlocutors' repeated assertions, it became increasingly apparent to the authors that the vast majority of women's decisions to engage in sex work could only be understood in the context of worse labor choices on these women's horizon of possibilities: choices that the women themselves repeatedly qualified as "more exploitative" and "more objectifying" than sex work.

In 2010, authors Blanchette and Da Silva had occasion to spend two weeks in New Orleans, a city in which Blanchette had briefly worked as a sex worker (stripper) in the late 1980s. Both authors were also in touch with the organized sex workers of New Orleans and had been closely following the city (and the State of Louisiana) as it attempted to revamp its sex laws and policing practices, particularly in the post-hurricane Katrina period and in the light of the growing anti-trafficking moral panic in the U.S. The authors took the opportunity to engage in some 100 person hours of fieldwork in New Orleans' Bourbon Street district. Following Emilé Durkheim's dictum that one should close in on social phenomena through their most obvious and publicly noted manifestations and given Blanchette's personal connections to New Orleans, Blanchette and Da Silva felt that a brief application of the same methodologies they employed in Brazil in what is one of the U.S.' most notorious commercial sex districts would provide an elucidative comparison to the work in Brazil. Although such fieldwork would be, by nature, superficial, it would be mostly dedicated to checking hypotheses in another environment. Besides, much of the 
received knowledge regarding prostitution and trafficking of persons in Brazil produced by non-Brazilians focuses on an almost continental-sized field, often with similar amounts of time (or even less) spent in Brazil and little to no knowledge of the local language and cultures. What the authors intended to do in New Orleans was far less ambitious. In the event, their fieldwork provided them with 16 non-structured interviews regarding sex and work with erotic dancers (many of them also prostitutes) and the testimony of dozens of other actors (police, barmen, cab drivers, hotel workers, service laborers in general) in and around New Orleans' sexual economy.

\section{Results}

\subsection{Scenes from Fieldwork, Part 1: Stripping for Burghers versus Flipping the Burgers}

It is 3 a.m. on Bourbon Street, New Orleans, one of the most celebrated entertainment districts in the world. Bourbon Street has what author Da Silvas' great aunt would call "a reputation" and millions of dollars move about every year in order to maintain that reputation. By day, the street is dominated by souvenir shops hawking trinkets made on an industrial scale in China. When the sun goes down, however, a bar opens on every corner of the street and a strip joint comes alive on every block.

The entertainment offered is surprisingly standardized. Go into any outlet selling "Hurricanes" (a local drink) and you'll find the same "freezie" machines producing the same drink flavors under the same neon lights to the same canned jazz. The sex sold on Bourbon Street is similarly standardized: stripping is allowed, but prostitution is prohibited and strippers cannot be $100 \%$ naked. For researchers whose eyes are conditioned to Rio de Janeiro, the relatively prim titillation of Bourbon Street looks like a brothel district as conceived and managed by Disney. The street is a carefully oiled machine, designed to efficiently extract cash from the multitudes passing along it. The entrance price for each venue is low (USD 5 or less) but everyone charges something. The feeling as we pass along Bourbon Street is that our wallets are being efficiently vacuumed.

"The thing is to keep the tourists drunk", explains Frances, a young barwoman from Salvation, one of the strip joints we visit. "This is why every house gives you a free drink". She points to the enormous plastic syringes filled with a mixture of gelatin and grain alchohol that were pushed into our hands when we passed through Salvation's door.

A guy sucks down one of those and he's ready for anything. Here on Bourbon, the fun is $24 / 7$. This is a problem for many tourists. They've never been to a place where they could drink as much as they want.

We'd later see one of the consequences of this. When we leave Salvation we almost stumble into a large pool of blood, solidifying in the gutter in front of the club. We asked a police officer what had happened. "A tourist from Florida was so drunk that he walked into the streetlamp", he answered. "He broke his nose".

Watching the women dance around the poles in the center of Salvation's stage, we are impressed with how much control they have over the situation and how their work is based on individualized performance. Each dancer is introduced by name (invariably false) and has a group of regular customers who come in just to see her. In total, $40 \%$ of the people watching the show this night at Salvation are women. Customers cannot touch the dancers and will be kicked out if they try. Dancers, however, can touch customers.

We chat with two dancers at the bar: Tiffany and her colleague Candy, both women in their 20s. We asked if they felt exploited at Salvation. Tiffany (who admitted to selling sex on the side "in the past") shook her head vigorously. "We're not the ones being exploited here!"

It's the tourists who are exploited. I do my show on the days I want to, the way I want to. If I want to approach someone in the audience, I can. If I want to stay the hell away, I can. It's all about how much money I want to make. These guys [indicating the 6 men and 4 women seated around the stage, watching Tiffany's colleague Amy dance] will probably to leave here without a penny in 
their pockets. All of this is to get them drunk and spending. I only make money here: I don't lose it like they do.

Tiffany is not being 100 percent honest. Dancers have to pay to work at Salvation, handing the house between 20 to 60 dollars depending on the time they want to arrive. Dancers also have to tip the DJ and the other house workers when they leave. Officially, the dancers are "independent contractors" who come in between one and four days a week. They dance once every 1 to $2 \mathrm{~h}$ and earn 10 to 20 dollars in tips from customers for each dance. They can also sell special "lap dances", where they rub their body on the customer, earning 20 dollars a dance.

Tiffany doesn't want to talk to us about how much money she took typically takes home, but Frances later tells us the club's dancers could earn much more than USD 100 a night: almost double New Orleans' minimum wage of USD 7.25 an hour. "They earn way more than me and I make 100 a night on a good night".

We ask if the dancers are well treated by the customers, Tiffany gives a sharp laugh. "This is a titty bar, for fuck sake!" she said. "The guys don't come in here to get to know me as a person. But the majority of them are nice people".

"Security here is great", says Candy. "If I have any problems with a customer, the guy will be kicked like that! [snaps his fingers]. But I usually have no problems. Customers know the rules and don't abuse them".

We ask Tiffany if she feels objectified by the customers when she dances.

"What a stupid question!" said Tiffany, giggling.

Stripping can suck, but I make a lot and it's not as bad as other jobs. I don't even want to imagine what it must be like to work at a Quartz [a local fast food joint, popular in New Orleans]! One of the cool things here is that I am not the target of as much sexual harassment as I was when I worked in restaurants. Customers touch me, of course, but only if I touch them. I control the interaction and the bosses here leave me alone. That was not the case when I worked as a waitress.

Anthropologist Katherine Frank (2002), who worked as a stripper in clubs in the southern United States during graduate school, agrees with Tiffany on the importance of interaction between dancers and customers: this is an economy that rewards women who manage to individualize themselves in the minds of spectators. Individualized performative interactions between the two are an extremely important part of the experience. According to Frank, "I had to find out, quickly, what kind of interaction the man wanted. I finally learned to look at the entire room, analyzing customers to make immediate and accurate decisions about how I should present myself ... " (Frank 2002, loc201-202, 374-377).

Frank points out that strip clubs obviously incorporate configurations of power and privilege that place certain people as workers and others as consumers in a scenario centered on sexual fantasies. Dancers are not simply objects in this environment, however. They "respond actively to customers, resist the control of club managers and owners in a number of ways and express their own sexualities and desires, even in a situation dedicated to male fantasies". (Frank 2002, loc497-505).

In other words, although men (and some women) enter the club to see dancers "shake their tits", our interlocutors and Frank would agree that this is not the main thing they sell. Ultimately, to be successful, dancers need to sell fantasies that require creative symbolic interactions with customers.

Objects are unable to produce these.

Our time in Salvation did not given us many examples of hard-core exploitation of objectified, machine-like humans. However, it didn't take us long to find a glaring example of this once we left the club. It was almost 4AM and we were hungry. Fortunately, at the end of Bourbon Street, we found a restaurant that was still open: a Quartz fast food stand. In this tiny space, under merciless fluorescent lights, six very young black women ran about serving the customers, a dozen night walkers who, like us, were headed back home after an evening on Bourbon Street. ${ }^{2}$ 
The two workers behind the cash registers were economical in their interactions with customers, spending an average of $20 \mathrm{~s}$ to take orders and pass them on to the girls in the back who ran the grills and fryers. The employees barely communicated among themselves beyond what was strictly necessary in the fulfilment of their functions. Carmen Rial, a Brazilian anthropologist who worked in a burger joint during her doctoral studies in France, describes this sort of labor and her specific work as a producer of full Coca-Cola glasses as follows:

I must arrange the glasses according to their different sizes, fill them with ice, place them under the jet of the correct soft drink, as indicated on the machine, choose the small or large button according to the amount of drink desired, press the button and wait for the glass to be full and for the machine to stop, close it with one of the plastic lids arranged in two rows (large and small) and, finally place the glasses in the right space so that another colleague can pick them up. This operation was repeated indefinitely. (Rial 1997, pp. 2-3)

Rial felt that her work transformed her into a mere extension of the soft-drink machine she serviced, a situation which she found to be inhumanly objectifying. Aside from having her body mechanized and objectified, Rial also found herself being incorporated as a faceless, interchangeable, and disposable part in her new corporate "family" (for it was this term that the company used to describe its relationship with its employees). "I had enlisted in a kind of army where one received many orders and reprimands, but very few medals" (Ibid, p. 3).

Everyone knew my name because I had a little label attached to me, as if I were a tree in a Botanical Garden. The word "Quick" [her company] came just below my name. Quick could thus be seen as the surname common to all of us, made brothers and sisters by the desire to pocket 24 francs an hour preparing hamburgers for a population of consumers who huffed with impatience on the other side of the cash registers. (Ibid, p. 2)

Sensitized as we were to questions of labor, objectification, and exploitation by our hours in the strip clubs on Bourbon Street, the situation of the workers at Quartz hit us hard. Here was a living representation of what Tiffany wanted to avoid by working as a stripper: the transformation of a human being into a small cog in a production machine; a disposable object functioning for an unlivable minimum wage to create corporate capital.

Here, then, was full-on objectification and exploitation.

\subsection{Scenes from Fieldwork, Part 2: "I Will Not Be Dona Maria!"}

Cilda had only one regret about her career as a prostitute in Porto Preto, a petroleum town a few hours north of Rio de Janeiro ${ }^{3}$ : "I just wish I had learned about this whoring thing years ago".

I came into the life when I was almost 40. These girls here [points to other prostitutes in the bar] don't know what they are doing. Oh, if only I had the body I had at 25 and the head I have today!

Though Cilda is considerably older than the average prostitute and has only been selling sex for six years, she has traveled twice to Europe and owns two houses in a nearby beach town. She commands a respectable fee of 100-400 dollars per "program" (trick).

Before becoming a prostitute, Cilda worked with her (now ex-) husband in her own catering business. This went bankrupt because her husband got involved with drugs. Cilda left him, sold what she could of the remaining equipment and her house in Rio de Janeiro, and migrated to Porto Preto. In her first jobs in the city, Cilda worked in exchange for food and board for free, usually as a waitress and maid for bars and restaurants. It was there that she started meeting women who sold sex:

They seemed to be happy and pleasant young women who made in one night what I earned in a month-when I earned anything at all. So I asked myself, 
"Why am I working like a slave? Is there anything worse than working and earning nothing?" After all, what did I have to lose? My husband had not even been good for sex and I like sex. Having sex and getting paid for it couldn't be that bad. And it's not bad! I love my job. You can put this down right there [pointing to Author One's field notebook]: I love being a "program girl" [a woman who sells sex].

It is interesting to note the choice of the word that Cilda used to describe her previous jobs as maid and waitress: slave. That word has been much employed by people who use it to describe the sexual exploitation they feel is inherent in prostitution. Cilda, however, uses it in the sense of "having to work without being paid", a state which she considered to be truly exploitative, in frank contrast to prostitution.

Similarly, prostitution seemed to be a positive way for Cilda to negotiate the uncertainties of middle age. In Brazil, women over 40 are marked by sexualized stigma, according to anthropologist Miriam Goldenberg (2009). The statement by a 43-year-old woman that "My husband had not even good for sex and I like sex" is radical in a society that still opposes sexual manifestations made by mature women. According to Cilda, sex is not always good in prostitution, but this was also the case in her marriage, where sex also ended up being non-existent: "Better to have sex, even when it's not the best, than to have nothing, neh?"

When Blanchette asked Cilda if she felt "objectified" by her customers, she replied "I hope they objectify me!"

Although people say I look like I am 25 when I am like this [dressed], when I take off my clothes, you can see the difference. You think I feel bad when someone tells me I look sexy? If I am powerful with the body I have, imagine what I could have done when I was younger!

Cilda is not blind to the dangers of sex work, although she claims she has never been mistreated by a client. However, she compares her work as a prostitute favorably with other typically female jobs in Brazil, such as being a housewife and domestic worker:

At my age, society says I can only be two things: Dona Maria the maid, washing Madame's panties for a minimum wage; or Dona Maria, mother and housewife, waiting for her husband to come back from the bar and go limp in bed. I will not be Dona Maria!

As a wife, Cilda had her life savings destroyed by a drug-addicted husband. As a maid and bar worker, she felt she was a slave, working for nothing. As a prostitute, Cilda gained a modicum of physical and social mobility that she feels has brought her dignity and independence. She has bought designer clothes, expensive perfumes, traveled to Europe, and mingled with foreigners in the most expensive restaurants and bars in Porto Preto. Sex work provided Cilda with more options, more mobility, and more dignity as a human being than the positions of housewife, domestic, or service worker. With this mobility, Cilda has created her own identity as a metropolitan woman: in 2010, she was planning to migrate to the U.S. after having married one of her foreign clients. "My life has been very hard", she says. "But that's not why I became a prostitute: being a prostitute is what gave me everything I have and made me who I am today".

Cilda's story, however, did not end there.

Once again, marriage was not enough to provide for her desires. The strengthening of visa restrictions under the Obama and Trump regimes made it impossible for her to transform her marriage (conducted in Brazil) into residency in the U.S. Her American husband was not willing or able to help her with the bureaucratic hurdles this involved. The relationship dissolved when petroleum prices began to plummet in 2013 and Cilda's husband was reassigned to work in Louisiana. Ironically, the economic depression into which Porto Preto plunged pushed Cilda out of sex work because there simply were no clients to be had-particularly the foreign oil workers she favored. Instead, Cilda was hired as a cleaning woman on a semi-defunct offshore platform. While she still continued to turn 
tricks there, this was not sustainable because, according to her, "the Company watches everything you do $24 \mathrm{~h}$ a day and they fire any woman who has sex".

After social security and deductions for uniforms, equipment, room and board, Cilda takes home little more than the equivalent of two monthly minimum wages (about 350 USD as of late 2020). She appreciates the relative security her job offers her as a 53 year old woman, even in the midst of the oil bust: she has a formalized work contract and health care plan. When Blanchette asked her if she felt exploited now as compared to when she worked as prostitute, Cilda quickly responded "Certainly! The Company owns me now".

But I am still no Dona Maria! I could quit tomorrow if I wanted to, because I have my houses. I could live in one and rent the other. It' $\mathrm{d}$ be a miserable existence, but if I could do it. And why could I do that? Because of prostitution. If I hadn't been a program girl, I'd have no choice at all. As it is, god willing, I will be able to retire, even on the pittance they'll pay me, because I pay no rent. I am free and clear.

Even in her "golden years", then-which, if all goes well, will be spent as a poorly paid corporate janitor-Cilda recognizes that the eight years she spent selling sex created openings in her horizon of opportunities. Far from seeing sex work as "exploitation", Cilda once again favorably compared prostitution to formal labor for a company that "owned her ass" and felt entitled to control her sexual behavior through $24 \mathrm{~h}$ a day surveillance.

\section{Discussion: Exploitation and Objectification as Categories in Thinking about Sex Work}

Looking at the five types of engendered labor described above-erotic dancer, fast food worker, prostitute, housewife and unpaid (or underpaid) maid-we can see varying degrees of danger, stigmatization, agency, vulnerability and profitability. What can these jobs tell us about exploitation?

Prostitution researchers are often quick to denounce the idea that a "real choice" can be made between forms work of this sort, given the structural limitations imposed on female labor by a patriarchal and capitalist socio-economic system. Julia O'Connell Davidson (2002) articulates this position well when she observes that it is "economic compulsion that drives [women] into sex work" in the U.S. to avoid becoming part of the $35 \%$ of the economically active female population of that country who earn an unlivable wage. The situation for working women in Brazil is worse, by any measure.

However, in more than 15 years of sex work ethnography, we have yet to find more than a small handful of women who feel that prostitution is more exploitative than the other sorts of poorly paid engendered labor they have done, or that they were "forced" into prostitution. In fact, even 60-year-old Cleone Santos, the only major sex worker leader in Brazil who calls for the abolition of sex work, recognizes that the senior citizen prostitutes she represents engage in other forms of labor where they are even more exploited.

Sex work is far from these women's last option in life, as Cilda once nicely illustrated to Blanchette while watching Les Miserables. Seeing Fantine sell her hair, then her teeth, and only then sex to support her daughter Cosette, Cilda clucked her tongue and commented "Oh, dearie ... You're going about things entirely the wrong way". Similar to Cilda, the large majority of our interlocutors who have sold sex and have moved on to other forms of labor often compare these jobs unfavorably to prostitution, even as they recognize that there are much better jobs available to women who are not them.

This sentiment is well expressed by self-proclaimed putafeminista Monique Prada, former president of the Central Única dos Trabalhadores do Sexo (Central Union of Sex Workers-CUTS):

Basically, prostitution is a place where common sense says no woman should want to be-and yet millions of women have exercised it through the centuries. Perhaps this is far from the worst place in the world for a woman, but there is a whole society striving to make it lousy ... And there is a class of people-and I belong to that class of people-for which working with sex, cleaning toilets, or 
changing diapers of old people are the possible jobs, worthy work, and we do this work. Unfortunately, in the society we live in, we need to keep in mind that not all people have such a wide range of choices which permit them to stay away from precariousness or abusive bosses. Nevertheless, we continue to live and continue to make the choices that are within our reach. (apud Drummond 2017)

Neither Monique nor our sex-selling interlocutors would qualify prostitution to be "a job like any other", a position that is often attributed to the prostitutes' rights movement by prohibitionist feminists. They recognize that prostitution has its specificities, "like any job does". They recognize that, like many other jobs-and, in particular, engendered women's work-it can be dangerous, dirty, and tiring. They recognize a series of "exploiters" involved in sex work: owners of nightclubs, spas, escort agencies and (most particularly) the police. These are people profit from their sex work, extracting a significant amount of surplus from it.

However, as Betânia Santos, sex worker, president of the Warrior Women prostitutes' rights association in Campinas Brazil and Workers' Party activist, constantly reminds her interlocutors, while prostitution is not "just any type of work" it is work-and productive work at that, in the Marxist sense of the word (Da Silva and Blanchette 2017). Productive labor under capitalism necessarily means exploitation in the Marxist sense of the word-the extraction of capital from labor. However, the solution to this is, and always has been, in Santos' view, worker organization and worker rights: not the repressive policing of those who are understood to be exploited.

None of what we have outlined above should be news to anyone who has "shared time" (Fabian 1983) in great quantities with sex workers. This is typically not the case of the prohibitionist wing of feminist thinkers. These people are notably intellectually led by philosophers, journalists, social workers, psychologists, and legal scholars who (going by their published CVs) seem to have shared very little time with sex-working women.

Prohibitionist thinkers actively repel the notion of sex as work, seeing the sale of sex as a special form of exploitation-sexual exploitation. They thus classify prostitution as morally distinct from work (even other forms of work involving sex, such as marriage) and see it as a synonym for human trafficking and/or slavery. In the view of these feminists, what is bought and sold in prostitution is the totality of a woman's ${ }^{4}$ body and person. The sale of sex thus becomes "a mutation of modern or even postmodern society. A reification of barbarism" (Leal et al. 2007, pp. 18-19).

At the heart of this difference between sex workers' (and most particularly putafeminista sex workers (Blanchette and Da Silva 2018)) and prohibitionist feminists' views of exploitation lies a concept of totalizing objectification, whereby a woman's accepting money for sex so completely transforms her that her body and, indeed, her very self becomes congruent with the sex act. She - and not the sex-becomes an object that is bought and sold, completely destitute of human agency. A slave. Worse: a slave to which any power of possible rebellion is denied, one who can only be freed by outside intervention. Because of this, these feminists often believe in the need for the criminalization/medicalization of sex workers, conducted by what Dewey and Germain (2016) label "the Alliance": police and social work agents acting in tandem to round up and reform prostitutes. Their views have powerfully influenced laws, such as the Swedish client criminalization law and the U.S.' current SESTA/FOSTA Act (Murphy 2018).

Where does this totalizing (and yet curiously limited) concept of objectification which underlies the concept of sexual exploitation come from?

To answer, we need to investigate the concept of objectification and how it has appeared within Western thought, particularly in the context of sex work. We do not intend to exhaust this topic here, of course. Obviously, a more in-depth investment would engage deeply with the philosophical roots of the concept of objectification and, in particular, those of feminist thinkers (MacKinnon 1987, 1989; Dworkin 1987, 1989, 2000; Nussbaum 1995; Langton 2009 among many others) who have dialogued with these roots over the years. 
The present discussion follows Alan Soble (2002) and Evangelina Papadaki $(2007,2010)$ investigations into how prohibitionist feminism's philosophical approach to the overlapping issues of sexual objectification and exploitation hides, at its base, a contradiction. By adopting Immanuel Kant's views on Kant's understandings of (im)moral objectification as their guide, prohibitionist feminist thinkers such as Dworkin and MacKinnon have, ironically, aligned their approach to human sexual/affective exchange with that the male philosopher (Kant) whom modern feminists tend to regard as the most objectionable (Herman 2002) - a man who died at 80 years of age a confirmed bachelor and virgin.

Objectification as a category of social analysis does not appear as such in most works in the social sciences, but something similar is at the base of the thoughts of the classical authors in the field. Emile Durkheim, for example, was concerned with the concept of anomié - an antisocial state that could be created by a progressive division of labor that would be in danger of reducing the individual to the role of machine, "becoming nothing more than an inert gear that an external force sets in motion and that always moves in the same direction and in the same way" (Durkheim 1998, p. 100).

Karl Marx wrote almost nothing about objectification, but quite a bit about commodification and the transformation of labor into a form of alienable merchandise under capitalism. Marx makes a crucial distinction between free and enslaved labor. The first form could be transformed into merchandise and alienated from the worker's life with deleterious effects: "life begins for [the worker] where this activity [work] ceases; at the table, in the public house, in bed. [His work] has no meaning for him [as such] except as the earnings that bring him to the table, to the public house, to the bed" (Marx and Engels 1986, p. 75). Marx, however, openly opposed this to slave labor, wherein life became a commodity "which can pass from the hand of one owner to that of another" (Ibid, idem).

For Marx, the advent of capitalism completely changed the relationship between humans and work and, consequently, human relationships with the body. The key point of labor relations under capitalism is the fact that labor is transformed into a saleable object separated from the life of the worker. In Marx's words, "the worker does not belong to the owner or to the land, but eight, ten, twelve, fifteen hours of his daily life belongs to the one who buys them" (Ibid, idem). The worker is nobody's and she can leave her job at any time. However, since her life depends on the sale of her labor, she cannot escape the class of labor buyers without renouncing her existence. She thus "belongs" to the capitalist class and must find a buyer for her labor or die. This, according to Marx, was the essence of exploitation under capitalism (Ibid, pp. 75-76).

While both Durkheim and Marx stressed the division of labor's dangerous potential in transforming the individual into an object or alienating her from the very production created by the activity of her body (Marx and Engels 1986, p. 90), sociologist Georg Simmel emphasized the leveling role money played, particularly when it completely dominated the economy. By reducing the value of all things to a single question- "How much?"-money could become "a frightful leveler - it hollows out the core of things, their peculiarities, their specific values and their uniqueness and incomparability in a way which is beyond repair" (Simmel 1971a, p. 337).

With the advent of complete domination of the economy by money under capitalism, things lose their essential characteristics, as everything can be expressed in terms of monetary value. In this money-driven economy, personal services are likewise expressed in coins and, therefore, in terms of exchangeable objects. A lap dance at Salvation, for example, is worth eight hamburgers at Quartz, a T-shirt from the New Orleans Saints, or two tickets to a show by jazz artist Kermit Ruffins. A "program" with Cilda is worth the equivalent of the monthly salary of a maid or a dinner at the chic restaurant where Cilda once worked for free. From the buyer's point of view, the distinction between all these goods and services depends mainly on the buyer's desire for consumption: all their innate qualities are reducible to a comparable quantity through money.

We could continue with this analysis of the concept of objectification through the lens of classical sociology; however, the general positioning of the discipline, at least up 
to the first decades of the 20th century, seems to be clear: as societies are transformed via capitalism, urbanization, and the increasing division of labor, interactions between human beings attenuate and end up becoming more utilitarian and fragmented. The bulk of humanity begins to seem more and more as objects, distinguishable only in terms of the different functions they fulfill. The services and products that they do or make are alienable from their person and, precisely because of this alienability, the leveling effect of money, and the utilitarianism of the daily social life of urban capitalism, the individual worker is always in danger of becoming an object in the eyes of those who buy their time. In Durkheim, Marx, and Simmel there is great discomfort with the notion of division of labor and a suspicion that this could end up in the creation of de-socialized human beings who could be easily interchangeable with objects.

Sociological thinkers such as Marx, Durkheim, Weber, and Simmel were haunted (in the sense given to that word by Avery Gordon 2010) by the progressive elimination of a moral organization where work was synonymous with human dignity and close social ties made sense of individual existence. They feared the effects of urbanization and capitalization precisely because these threatened to eliminate the old moral order while threatening to reduce the human being to a small cog in the production machine. The nightmare of exploited and alienated man-machine object permeates the essays of these classic sociological thinkers.

As we have mentioned above, objectification is also a catchphrase of the second wave of feminism that developed out of the 1960s. In particular, it is employed by prohibitionist and anti-porn feminists to indicate the effect that prostitution is supposed to have on the bodies and beings of the women who sell sex. Used by classic radical anti-porn feminists such as Catherine MacKinnon (1989) and Andrea Dworkin $(1987,1989)$, but also by more moderate thinkers such as Martha Nussbaum (1995), the concept is generally employed to indicate attitudes or practices that treat human women as utilitarian objects to be exploited. In the context of sexual objectification, it indicates the practice of treating women as an instrument for the gratification of male sexual desires: a means to an end rather than an end in itself.

Something of this understanding can be seen in Laura Mulvey's approach to the psychology of the male gaze in her critique of how women are portrayed in cinema (2009). Mulvey and other Lacanian-influenced feminists do not seem to grapple with are the other ways in which supposedly subordinate Others are rendered invisible. Mulvey's analysis, in particular, does not seem to engage with the fact that only certain female bodies are hyper-sexualized: precisely those of women who appear to activate male castration anxieties. This, in turn, implies that the presence of said female bodies must be recognized as potentially having power over the man in question. They evoke, in short, the fear of punishment from mother (or father) figures. It is not the "mere presence" of any woman on screen that leads to her oversexualization as a male subversion and defense.

Hollywood is full of non-sexualized women which Mulvey-let alone the putative male spectator-does not even appear to consider to be women-or even fully human-per se. These are the legions of female extras who play the roles of maids, cooks, educators, etc. They can be sexualized, yes, but only to the degree that they are even considered at all as part of the story. It shouldn't be a surprise that so many of these "non-extant" characters are not white or are marked by other indicators of alterity. Employing Mulvey's theories on sexual objectification and the male gaze, one can clearly see why Scarlet O'Hara must be sexualized. How do her theories account for Mammy? Female laborers in traditional cinematography are so instrumentalized by class and race-infused gazes that they often do not even register as women. This is an "objectification" that goes quite beyond sexualization and the Freudian and Lacanian theories that support Mulvey's analysis. It is also the sort of "objectification" that our Brazilian and American sex-working informants repeatedly point to when they talk about leaving "worse" jobs for sex work.

Black feminists seeking to recover black women's sexual agency have questioned the presumption that sexual objectification is the nee plus ultra of female degradation. Mireille 
Miller-Young's work (Miller-Young 2014) has investigated black female sexuality in the context of the production of pornography, revealing its ambiguities as both a "weapon of the weak", a form of self-affirmation, and a means of reproduction of sexualized black stereotypes. Ariane Cruz (2016) has likewise explored how black female performance in sexual labor (in the context of the production of BSDM pornography) is likewise not simply identifiable as "objectification" but is rather a complex and mutable negotiation and even a contestation of power. Our own work in this field — spearheaded by Da Silva (Da Silva and Blanchette 2017)—has shown how "sexual objectification" ("being forced to work like and with men", in the context of racist and engendered labor in rural Rio de Janeiro can be preferable to retaining female bourgeois respectability, creating for the women who choose this path greater opportunities for power and wealth accumulation than the poor or unpaid labor performed by the women who are not sexually objectified on the silver screens Mulvey analyzes.

Following feminist Elizabeth Schussler-Fiorenza's intersectional analysis of kyriarchy in classic Greek patriarchy (Schussler-Fiorenza 1992), Da Silva characterizes the kind of feminism that fears sexual objectification as the worst sort of degradation as madame feminism: the feminism of the (ex)slave-holding class. As the (mostly brown and black) menial laborer and sex worker experiences Da Silva collects in her fieldwork indicate, to be paid to be "sexually objectified" is often a large step up for women who otherwise are only objectified for their brute labor power, precisely in the manner Rial describes fast food workers as being objectified, above (Rial 1997).

It is in this context that one should remember the old racist and sexist Brazilian folk saying reported by anthropologist Gilberto Freyre, which neatly lays out the hierarchy of objectifications available to women in colonial Brazil: "White women for marrying, mulata women for fucking, black women for work" (Freyre 1933, p. 48). ${ }^{5}$ As we have pointed out elsewhere (Blanchette and Da Silva 2018), for women in the lowest reaches of Brazil's economy, often the only liberty available-and the only means to possibly construct a better future, escaping this tripartite destiny-is to be able to shift oneself from one to another of these positions, more or less at will. We thus believe that "Sexual objectification" as it has been conceived of by feminists such as Mulvey can only be understood within the contexts of other engendered forms of intersectionalized objectification within the constraints of a greater theory of labor objectification, such as those explored by Alan Soble $(2002,2003)$.

The employment of objectification as one of the worst forms of degradation women face has been criticized by feminists from the sex positive school (for example, Camille Paglia (1992), Alan Soble (2002, 2003); Evagelia Papadaki (2007, 2010), but it remains one of the most popular concepts of feminism, as recent publications by essayists and journalists such as Ariel Levy (2005) and Robert Jensen (2007) and the constant use of the term in the feminist blogosphere testify.

According to the philosopher Evangelia Papadaki $(2007,2010)$, this feminist appropriation of objectification has its roots in the idealistic and pre-capitalist philosophical thought of Immanuel Kant (1724-1804). According to Papadaki, MacKinnon and Dworkin and their followers describe sexual objectification and exploitation in terms that are very similar to those used by the German philosopher. They portray it a process that involves treating a woman as a mere instrument for the purposes of male exploitation, in such a way that the woman is reduced to status of an exploitable object. Papadaki points out that for Kant, Dworkin and MacKinnon, "objectification involves treating a person as if they were an object (a mere sexual instrument), in such a way that this leads to the reduction of the individual in question to the status of a thing to be used (a lemon, a steak, a glass). For all these thinkers, then, objectification therefore constitutes a serious damage to a person's humanity" (Papadaki 2007, pp. 340-41).

Interestingly, Kant also provides the basis for the classical sociological understanding of prostitution, created by Simmel (1971b), which adds to the German philosopher's thoughts on the notion that the degrading and leveling nature of money reinforce the 
objectification of the prostitute. Simmel, in turn, has been a touchstone for later generations of sociologists trying to come to terms with the sale of sex.

Given Immanuel Kant's contributions to both the classical sociological and second wave anti-porn feminist views of prostitution - both of which have heavily influenced laws against sexual exploitation — we thus need to turn to Kant and ask what he thought about sex and objectification?

Immanuel Kant was born in Königsberg, in East Prussia in 1724 and became one of the best known founders of German Idealism. The East Prussia of Kant's day still largely followed the rhythms of the pre-capitalist world and, during his life, Kant never traveled more than $70 \mathrm{~km}$ away from his hometown. Furthermore, even for the time and the place in which he lived, Kant was very singular. In the words of Paul Strathern (1996, p. 12), his life was marked a by sexual repression that reached "heroic proportions", with Kant dying at the age of 80 , apparently still a virgin.

Kant's observations on sexual objectification are well known. His basic position can be summarized by the following quotes, from Readings on Ethics:

Man has an impulse directed to others, not so that he may enjoy their works and circumstances, but immediately to others as objects of his enjoyment ... This is the sexual impulse ... In loving from sexual inclination, [man makes] the person into an object of their appetite. As soon as the person is possessed, and the appetite sated, they are thrown away, as one throws away a lemon after sucking the juice from it ... [T] here lies in this inclination a degradation of man; for as soon as anyone becomes an object of another's appetite, all motives of moral relationship fall away; as object of the other's appetite, that person is in fact a thing, whereby the other's appetite is sated, and can be misused as such a thing by anybody. (Kant 1997, pp. 155-56)

This is quite a singular view of sex, although perhaps one appropriate to a virgin raised in strict German Pietism, such as Kant. Prostitution is particularly alarming in this ethical construction, so much so that the philosopher qualifies it as the actual physical sale of the body, confusing the person of the prostitute with the "property" her body becomes when she supposedly "sells it" (ibid, idem). Kant gives no reasoning behind his belief that the sale of sex meant the sale of the body: he simply states this as a fact, a priori.

Kant saw the sexual act as being fundamentally unlike other forms of human interaction. It was a totalizing act, in which a human being was literally given to their partner in their entirety: body and soul. Kant's thoughts on this led him to create the concept of crimina carnis (Ibid, pp. 160-61), which he establishes as any sexual act not contained within the bounds of heterosexual monogamous marriage. According to Kant, marriage was the only ethical way sexual activity could ethically occur because "if I give myself completely to the other and get the other back in return, I gain myself again" (ibid, p. 158).

But in Kant's ethical philosophy, sexual activity stands in stark contrast to his other claims about the ethical uses of the body. For example, the philosopher thought that it was completely possible for man to "enjoy the other as an instrument for his service: he can utilize the others' hands or feet to serve him, though by the latter's free choice". (Ibid, p. 155). Hiring hands and feet as instruments alienated from a human totality was thus perfectly ethically acceptable to Kant, if everyone gave their consent and as long those body parts did not do anything sexual. Using one's hand to cut a gentleman's hair or dress them and receiving pay for this service was not "selling the body" as if it were an object. If the hand were to slip downward and masturbate the same gentleman for filthy lucre, however, the hand mystically becomes something that cannot be separated from the server's self and is qualified by Kant as "selling the body". Note that consent plays no role at all in setting this sort of activity beyond the ethical pale for the old idealist: by essence and nature sexual acts transform the self into a body that can only be given in its totality. The sale of such an object would thus, obviously, be slavery. To profit from the sale of such an object would be exploitation akin to the sale of slaves. 
Papadaki follows Barbara Herman in trying to explain this division in Kant's thought, appealing to the fact that the philosopher was concerned with instrumentality and feared that sex could allow a person to be treated as a mere means for the ends of their lover, and not as an end in themself. "For Kant", she explains, "objectification meant seeing a person as an 'object, something that could be used'" (Papadaki 2010; Herman 2002, p. 57). We agree with this understanding of Kant, but the basic question still remains: why does the danger of objectification exist in sex, but not in the more general "enjoying the other as an instrument of service"? This question takes on another dimension when we consider the fact that Kant treated his manservant Martin Lampe and the members of his family in a way that was arguably extremely instrumentalist (Strathern 1996, p. 40).

According to Papadaki, feminists of the MacKinnon and Dworkin school follow Kant in their understanding of inequality as something that is deeply intertwined with objectification and thus exploitation. In fact, the biggest difference between the positions of these feminists and Kant is that the first group does not understand marriage as a solution to the problem of objectification. According to both Dworkin (1989) and MacKinnon (1985), marriage, under patriarchal conditions, also risks turning women into slaves. In this reading of reality, heterosexuality creates a powerful objectifier and a powerless enslaved victim. Because of this imbalance of power, the first objectifies and exploits the second and the only ethical solution to this dilemma is the imposition of the law (Papadaki 2010).

Our experiences observing sex work in both the United States and in Brazil, detailed above, indicate that power, objectification, exploitation, and sexuality can rarely be understood in such simple and direct terms. Social relationships can and do include dominant individuals who command and others who must obey. However, in none of the jobs observed by us or discussed by our informants could we say that power was absolutely inherent on one side of the social equation and totally lacking on the other. Certainly, then, we need a more nuanced and multifaceted way of talking properly about objectification and the links that this has to exploitation. At the very least, we need to recover the agency of the social actors engaged in labor, be it sexual or not.

Feminist thinkers Nussbaum (1995, p. 257) and Rae Langton (2009, pp. 228-29) have created a way of talking about multiple axes of objectification and power, identifying ten main characteristics of objectification, through which we can employ to analyze a situation as more or less objectifying. These are:

(1) Instrumentality: the treatment of a person as a tool for the purposes of the objectifier;

(2) Denial of autonomy: treating a person as if they had no autonomy or selfdetermination;

(3) Inertia: treating a person as if they had no agency;

(4) Fungibility: treating a person as if he were interchangeable with other objects;

(5) Violability: treating a person as if they did not have integrity over the limits of their own body;

(6) Ownership: treating a person as something that can be sold or bought by others;

(7) Denial of subjectivity: treating a person as if their feelings do not need to be taken into account;

(8) Reduction to the body; identifying a person with their body or parts of their body;

(9) Reduction to appearance: treating a person mainly in terms of how they appearsto the senses;

(10) Silence: treating a person as if they were unable to speak.

To the degree that exploitation increases with the objectification of human beings-a proposition that the classical sociological thinkers and today's prohibitionist feminists would almost certainly agree with-we can thus say that a form of labor that requires or encourages more of these characteristics is more morally exploitative, independent of the strict Marxist definition of exploitation. This would allow us to create an ethical understanding of exploitation that is neither strictly historical-materialistic, nor defined by the Christian sensibilities of an 18th century male pornophobe. 
Such comparisons' needs must be strictly ideographic and not nomeothetic, however. Assessments will vary, often wildly, according to the specific situations compared. In terms of what we observed in New Orleans, for example, we would say that the stripper is less objectified in according to characteristics 1, 2, 3, 4, 6, 7 and 10, but that the fast food worker has an advantage in 5, 8 and 9. We have visited other strip shows in Brazil and the USA; however, where the stripper's advantage over the fast food worker, in terms of exploitative objectification, would fall dramatically.

Another problem with the Nussbaum and Langton's list is that, although it intends to offer a "universal ruler" through which we can measure and attest to levels of objectification (and thus, presumably, of exploitation), such evaluations will inevitably be subjective. How to understand, for example, the fact that Katherine Frank, in her persona as "Kate the stripper", knows how to scan a room full of men and evaluate who is most likely to buy a lap dance and what attitude she should adopt to maximize her returns? Who is more "inert" or without agency in this situation? The seated man, whom Kate correctly evaluates as being a paying customer, or Kate because she will need to dance for this man in order to earn money? Who has more power: the customer who talks about his life nonstop, or the dancer who pushes him to speak so that he will spend more money on drinks and dances?

There is no way to answer these questions universally and objectively without stipulating, a priori, a set of moral conditions that would necessarily be rooted in a given socio-economic, political, and cultural position within the world. Nussbaum and Langton intend to offer us a cross-cultural scheme to measure and compare objectification, but only someone created within a certain worldview could believe that the content of words as "property" and "autonomy" was evident and panhuman.

Perhaps for these reasons, the debate on sexual objectification and exploitation has remained, in large proportions, in the same spot for almost two centuries now, at least within mainstream feminism and certainly within what Elizabeth Bernstein calls "carceral feminism" (Bernstein 2007) and (more optimistically) Janet Halley "governance feminism" (Halley 2018), both of which greatly overlap prohibitionist feminism. Halley questions why "governance feminism" so often appears to end up generating non- or even antifeminist policies:

Many feminist visions of emancipation have been left at the station when various governance trains took off: what Kerry Rittich calls the "selective engagement" of feminist ideas into governmental power has left some diamonds in the dust. Sometimes selectivity so overwhelms engagement, or defeat so swamps success, that-despite feminists' best efforts—a governance project simply should not be described as feminist at all. Sometimes the result will be vaguely recognizable but so alien, so transformed by adverse political forces, that the best possible term for it might be Nancy Fraser's designation of feminism's "strange shadowy version", its "uncanny double". Figuring this out without evading responsibility is one reason to study GF. It is an invitation precisely to take stock of the inclusions and exclusions-and the upsides and the downsides-across their full range. (Halley 2018, p. xi)

What seems missing in Halley's contemplation of feminism's "uncanny double" is that it is not at all uncanny for the kinds of women who are not recognized as women on Mulvey's silver screen: it seems, in fact, inevitable. We would argue, based on data, that the kind of feminism that arrests prostitutes to save them is, in fact, the expression of certain race and class interests. There is no mystery here, let alone a putative doppelganger of feminism: feminisms respond - and has always responded-differently to the different moral interests generated by different ways of living in the world, according to different axes of distribution of privileges and exclusions that extend far beyond "woman" as a marker of alterity.

Without a priori morality, it is impossible to respond to Nussbaum and Langton's list properly. If you follow a Christian, Kantian, and/or prohibitionist feminist orientation, sexual activity is, ipso facto, defined as a radically separate area of human experience 
which cannot be considered as work because it cannot. On the other hand, if you are a libertarian, liberal, and/or anarchist feminist, it is difficult to see in sex an activity that must be segregated from the market. In a social universe that has already alienated the sex from the human body, using sex to sell everything from automobiles to cubic zirconia, it seems ridiculous to say that an adult cannot decide to sell sexual services of their own free will.

Neither of these two positions, however, are very attractive to sex workers themselves, who are in the most precarious trenches of the class/race/gender battlefield, given the structural limitations imposed on female labor by a still patriarchal late-capitalist and racist socio-economic system. Faced with a structurally limited horizon of possibilities, they must choose between forms of labor which few of them would probably opt for, given the proverbial magical lamp and three wishes. Those who seek to create laws and regulations that limit the exploitation these women are subject to need to understand, however, that sex workers do not see this form of labor as "the last resort in the face of misery and exploitation": they see it as a possible way out of misery and exploitation. Working in Quartz, being a dependent housewife, being a maid: these are the jobs understood by our sex working informants as "the last resort". The narratives the women offer of these jobs and our observations of their cycles through them convince us that sex workers are not operating under some false consciousness, PTSD, or-more dramatic still-under the mental control of all-powerful pimps when they assess their lives in this fashion.

The central problem of the debate about sex work and exploitation is that it takes as its base a pre-capitalist notion of sexuality and humanity while ignoring or disqualifying as "unreal" the real choices made by real people under the real conditions of late capitalism or understanding these as the fruits of "false consciousness" (or of an inadequate relationship with Christ, etc.). The problem is, with the advent of capitalism as a global and hegemonic system, "objectification" becomes an inherent danger of work and the exploitation of the working class is generalized. Whatever the mitigating factors seen by Marx or Durkheim that militated against the absolute reduction of the working human being to a mere tool of production, the fact of the matter is that the logic of capitalism, monetarism and urbanization trends towards this absent organized struggle by the workers themselves.

This, then, is the synthesis that the growing Spanish and South American putafeminismo (Blanchette and Da Silva 2018) offers to this century old debate regarding exploitation, objectification, and the law. In its understanding of women as workers, labor as engendered, sex as integral to work, and work as integral to sex, putafeminismo creates the necessary ideological and mora; pre-conditions for sex working women to organize themselves as a class - if not in the Marxist sense, then at least in the Weberian sense-and fight for positions in decision-making as stake-holders in Halley's brave new world of "governance feminism". Only in this fashion can laws which sex workers themselves recognize as just be created to reduce the exploitation they-and more generally working class womencurrently struggle against.

It seems to us that the only way to properly reform prostitution law is via the same means which labor laws in general have been reformed in the west: through the political inclusion of self-organized sex workers at the decision-making table. We thus feel that feminists involved in "governance feminism" must put aside the hitherto hegemonic Kantian notion of "objectification" in their contemplation of "sexual objectification" and grapple with a more generalized "labor objectification", particularly as this is experienced by marginalized women who are currently excluded from many feminist discourses, most particularly within the realm of governance. To this end, it should be a feminist goal to nurture, support, and cultivate sex worker organizations as political actors.

Author Contributions: Writing-original draft, T.B. and A.P.D.S.; Writing-review \& editing, G.C. All authors have read and agreed to the published version of the manuscript.

Funding: This research received no external funding. 
Institutional Review Board Statement: Ethical review and approval were waived for most of this study as it did not involve human or animal subjects and it followed the Brazilian Anthropological Associations' guidelines for ethical research among human subjects. Interviews, conducted while collecting life and work histories during the run up to the 2014 World's Cup and 2016 Olympic Games in the state of Rio de Janeiro, were vetted by the Federal University of Rio de Janeiro, Macaé's Ethics in Research Committee, with the project enrolled on the Federal Goveernment's ethics in research platform, the Plataforma Brasil, as CAEE\# 55633816.8.0000.5699.

Informed Consent Statement: Informed consent was obtained from all subjects involved in the study.

Data Availability Statement: All data is held in confidence by the authors.

Conflicts of Interest: The authors declare no conflict of interest.

\section{Notes}

1 Prohibitionism is distinguished from abolitionism in the sense that the later seeks to create socio-economic conditions in which sex work is abolished without subjecting women to hardship or stigma. Meanwhile, carceralist prohibitionism seeks to use the State's repressive power to attack sex work without great concern for the effects this may have on sex workers, understood to be criminals, sex/gender traitors, or agencyless victims in need of State-remanded professional tutelage and "reform". We see this prohibitionist feminism to be well represented in the present generation in the works of Sheila Jeffreys, Melissa Farley, and Julie Bindel, among others, not to mention in the phenomena of so-called "right wing feminism" or woman-agencied anti-feminism, such as that being promoted by many Christian women's groups, not to mention Brazil's current minister of Human Rights and the Family, Damaris Alves.

2 We have consciously changed from the ethnographic present to the past here because the sin qua non of ethnography-sharing time (Fabian 1983) — was literally impossible with the highly mechanized and objectified Quartz workers.

3 The name of this city has been changed to help protect Cilda's anonymity, as it is a small town.

4 We emphasize women here, because these prohibitionist thinkers rarely recognize men as prostitutes and, when they do, seem to be almost entirely uninterested in discussing male sex work as exploitative.

5 "Branca para casar, mulata para foder e negra para trabalhar".

\section{References}

Bernstein, Elizabeth. 2007. The Sexual Politics of the 'New Abolitionism'. Differences 18: 128-51. [CrossRef]

Blanchette, Thaddeus Gregory, Ana Paula Silva, and Gustavo Camargo. 2014. Idealismo Alemão e o Corpo Alienável: Repensando a 'Objetificação' no Contexto do Trabalho Sexual. In Prostituição e Outras Histórias de Amor. Edited by S. Simoes, H. Silva and A. Fonseca. Niterói: Editora da UFF, pp. 101-21.

Blanchette, Thaddeus Gregory, and Ana Paula Da Silva. 2018. Classy Whores: Intersections of Class, Gender, and Sex Work in the Ideologies of the Putafeminista Movement in Brazil. Contexto Internacional, PUC-Rio 40. [CrossRef]

Cruz, Ariane. 2016. The Color of Kink: Black Women, BDSM, and Pornography. New York: New York University Press.

Da Silva, Ana Paula, and Thaddeus Gregory Blanchette. 2017. For Love or for Money? (Re)produtive Work, Sexwork, and the Transformation of Feminine Labour. Cad. Pagu. n.50. Available online: http:/ /www.scielo.br/scielo.php?script=sci_arttext\&pid= S0104-83332017000200314\&lng=en\&nrm=iso (accessed on 7 November 2020).

Davidson, Julia O'Connell. 2002. The Rights and Wrongs of Prostitution. Hypatia 17: 84-98. [CrossRef]

Dewey, Susan, and Tonia St Germain. 2016. Systemic Intimacies: Policing Street-Based Sex Work in a Western U.S. City. New York: New York University Press.

Drummond, Maria Clara. 2017. Voz do feminismo no Brasil, a prostituta Monique Prada fala para a Revista J.P. Glamurama. January 16. Available online: http:/ / glamurama.uol.com.br/voz-do-feminismo-no-brasil-a-prostituta-monique-prada-fala-para-a-revista-jp/ (accessed on 4 December 2017).

Durkheim, Emilé. 1998. Durkheim: Sociologia. Org. José Albertino Rodrigues. São Paulo: Editora Ática.

Dworkin, Andrea. 1987. Intercourse. Available online: http:/ / www.nostatusquo.com/ACLU/dworkin/IntercourseI.html (accessed on 10 October 2020).

Dworkin, Andrea. 1989. Pornography: Men Possessing Women. New York: E. P. Dutton.

Dworkin, Andrea. 2000. Against the Male Flood: Censorship, Pornography, and Equality. In Oxford Readings in Feminism: Feminism and Pornography. Edited by Drucilla Cornell. Oxford: Oxford University Press, pp. 19-44.

Fabian, Johannes. 1983. Time and the Other: How Anthropology Makes Its Object. New York: Columbia University.

Frank, Katherine. 2002. G-Strings and Sympathy: Strip Club Regulars and Male Desire. Durham: Duke University Press.

Freyre, Gilberto. 1933. Casa-Grande E Senzala. São Paulo: Círculo do livro.

Goldenberg, Miriam. 2009. Coroas. In Jornal do Brasil. Rio de Janeiro: Sociedade Aberta.

Gordon, Avery. 2010. Ghostly Matters: Haunting and the Sociological Imagination, Kindle ed. Minneapolis: University of Minnesota Press.

Halley, Janet. 2018. Introduction: An Ethic of Responsibility. In Governance Feminism: An Introduction. Edited by Janet Halley, Prabha Kotiswaran, Rachel Rebouché and Hila Shamir. Minneapolis: University of Minnesota Press, pp. ix-xxii. 
Halwani, Raja, Alan Soble, Sarah Hoffman, and Jacob M. Held, eds. 2018. The Philosophy of Sex: Contemporary Readings. London: Rowman \& Littlefield.

Herman, Barbara. 2002. Could It Be Worth Thinking About Kant on Sex and Marriage? In A Mind of One's Own. Feminist Essays on Reason and Objectivity. Edited by Louise M. Antony and Charlotte Witt. Boulder, San Francisco and Oxford: Westview Press, pp. 53-72.

Hernes, Helga. 1987. Welfare State and Woman Power: Essays in State Feminism. Oslo: Norwegian University Press.

Jensen, Robert. 2007. Getting Off: Pornography and the End of Masculinity. San Francisco: South End Press.

Kant, Immanuel. 1997. Lectures on Ethics. Cambridge: Cambridge University Press.

Langton, Rae. 2009. Sexual Solipsism: Philosophical Essays on Pornography and Objectification. Oxford: Oxford University Press.

Leal, Maria Lúcia Pinto, Maria de Fátima Pinto Leal, and Renata Maria Coimbra Libório. 2007. Tráfico de Pessoas e Violência Sexual. Brasília: Universidade de Brasília.

Leigh, Carol. 1997. Inventing Sex Work. In Whores and Other Feminists. Edited by Nagle Jill. London: Routledge, pp. $225-31$.

Levy, Ariel. 2005. Female Chauvinist Pigs: Women and the Rise of Raunch Culture. New York: Free Press.

MacKinnon, Catharine. 1985. Pornography, Civil Rights, and Speech. Harvard Civil Rights-Civil Liberties Law Review $20: 1$.

MacKinnon, Catharine. 1987. Feminism Unmodified. Cambridge and London: Harvard University Press.

MacKinnon, Catharine. 1989. Towards a Feminist Theory of the State. Cambridge: Harvard University Press.

Malinowski, Bronislaw. 1976. Argonautas do Pacifico Ocidental: Um Relato do Empreendimento e da Aventura dos Nativos nos Arquipélagos da Nova Guiné Melanésia. São Paulo: Abril Cultural. First published 1922.

Marx, Karl, and Friedrich Engels. 1986. Wage Labour and Capital. In Karl Marx and Frederick Engels: Selected Works. New York: International Publishers.

Miller-Young, Mireille. 2014. A Taste for Brown Sugar: Black Women in Pornography. Durham: Duke University.

Murphy, Meagan. 2018. INTERVIEW: Marian Hatcher Sets the Record Straight on the New U.S. Anti-Trafficking Bill, SESTA-FOSTA. Feminist Current. May 4. Available online: https://www.feministcurrent.com/2018/04/05/interview-marian-hatcher-setsrecord-straight-new-u-s-anti-trafficking-bill-sesta-fosta/ (accessed on 7 November 2020).

Nussbaum, Martha. 1995. Objectification. Philosophy and Public Affairs 24: 249-91. [CrossRef]

Paglia, Camille. 1992. Sex, Art, and American Culture. New York: Random House.

Papadaki, Evangelia. 2007. Sexual Objectification: From Kant to Contemporary Feminism. Contemporary Political Theory 6: 330-48. [CrossRef]

Papadaki, Evangelia. 2010. Feminist Perspectives on Objectification. The Stanford Encyclopedia of Philosophy. Edited by Edward N. Zalta. Available online: http:/ / plato.stanford.edu/archives/spr2010/entries/feminism-objectification/ (accessed on 10 October 2020).

Rial, Carmen S. M. 1997. Os fastfoods: Uma homogeneidade contestável na globalização cultural. Horizontes Antropológicos 5: 140-80.

Schussler-Fiorenza, Elisabeth. 1992. "But She Said": Feminist Practices of Biblical Interpretation, Kindle ed. Boston: Beacon Press.

Simmel, Georg. 1971a. Prostitution. In Simmel: On Individuality and Social Forms. Chicago University Press.

Simmel, Georg. 1971b. The Metropolis and Mental Life. In Simmel: On Individuality and Social Forms. Edited by Levine Donald. Chicago: Chicago University Press.

Soble, Alan. 2002. Dehumanization, Objectification, Illusion. In Pornography, Sex, and Feminism. Edited by Soble Alan. New York: Prometheus Books, pp. 49-79.

Soble, Alan. 2003. Kant and Sexual Perversion. The Monist 86: 55-89. [CrossRef]

Strathern, Paul. 1996. Kant in 90 Minutos. Chicago: Ivan R. Dee. 